\title{
PEMANFAATAN KELAPA SEBAGAI MINYAK DI DESA HARGOTIRTO, KECAMATAN KOKAP, KULON PROGO, YOGYAKARTA
}

\author{
Muhammad Fajar S. ${ }^{1}$, Ferdian Ravanelli ${ }^{2}$, Tessya Christara ${ }^{3}$, Maria Andreeana L. ${ }^{4}$, Yulia Oktaviani V. \\ Zefanya Atalya $^{6}$, Ruben Sebastian ${ }^{7}$, Maria Nariswari ${ }^{8}$, Mardyaning Christ C. ${ }^{9}$, Eudia Yulian H. ${ }^{10}$, Agustinus \\ Aryo Lukisworo ${ }^{11}$ \\ Universitas Atma Jaya Yogyakarta \\ Email: agustinus.lukisworo@uajy.ac.id
}

\author{
Received 03 Juni 2021; Revised - ; Accepted for Publication 29 November 2021; Published 30 November \\ 2021
}

\begin{abstract}
Kuliah Kerja Nyata (KKN) 79 started from April to May 2021 and was held online. In this period of KKN, LPPM distributed all the units into two main area, Kulonprogo area and Gunungkidul area. Both areas are located in Yogyakarta, Indonesia. As part of this KKN, our group was assigned in Hargotirto Village, Kulonprogo. Hargotirto Village itself has so many potencies, such as Gula Semut, Sekrasak Waterfall, Goat Farm, Fruit Commodities, and Coconut. In order to improve people's creativity and its economic conditions, the utilization of coconut as oil is a great opportunity. The data was obtained by researching through the internet by the village's website, journals, etc. The purpose of this journal is to provide informations on the utilization of one of the village's potency, the coconut.
\end{abstract}

Keywords: KKN UAJY, Hargotirto Village, Potency, Coconut Oil

\begin{abstract}
Abstrak - Kuliah Kerja Nyata (KKN) 79 dimulai dari bulan April hingga Mei 2021. Dalam KKN periode ini, LPPM membagi seluruh unit ke dalam 2 bagian utama, yakni wilayah Kulonprogo dan wilayah Gunungkidul. Kedua area tersebut berlokasi di kota Yogyakarta, Indonesia. Sebagai bagian dari KKN ini, kelompok kami ditugaskan di Desa Hargotirto, Kulon Progo. Desa Hargotirto sendiri memiliki banyak potensi, seperti gula semut, air terjun sekrasak, peternakan kambing, komoditas buah-buahan, dan juga kelapa. Untuk meningkatkan kreativitas masyarakat dan kondisi ekonominya, pemanfaatan kelapa sebagai minyak merupakan peluang yang sangat baik. Data yang ada didapatkan melalui media internet seperti website desa Hargotirto, jurnal-jurnal, dan lainnya. Tujuan dari jurnal ini adalah untuk menyediakan informasi tentang pemanfaatan salah satu potensi yang ada, yakni kelapa.
\end{abstract}

Kata Kunci : KKN UAJY, Desa Hargotirto, Potensi, Minyak Kelapa

\section{PENDAHULUAN}

Kuliah Kerja Nyata atau yang biasa disingkat dengan KKN merupakan suatu bentuk kegiatan pengabdian kepada masyarakat oleh mahasiswa melalui pendekatan lintas keilmuan dan sektoral pada waktu dan tempat tertentu. KKN juga merupakan kegiatan akademik yang wajib diikuti oleh seluruh mahasiswa di Universitas Atma Jaya Yogyakarta. Namun dengan adanya keterbatasan yakni pandemi Covid-19 yang sedang terjadi, maka kegiatan Kuliah Kerja Nyata (KKN) periode 79 ini harus diselenggarakan secara daring. Konsep KKN secara daring ini mengangkat tema yakni KKN Society 5.0 dimana kegiatan dilaksanakan tanpa adanya pengamatan langsung ke lapangan. Sehingga segala data yang didapatkan berasal dari sumber sekunder atau internet. Selain itu, karena kegiatan KKN hanya bisa dilakukan secara daring atau online maka output atau program kerjanya pun dihasilkan dalam bentuk file. Terdapat beberapa program kerja yang perlu dilakukan oleh setiap kelompok antara lain pengembangan potensi desa dan buku saku dalam bentuk video maupun $e$-book.

Pada dasarnya kegiatan Kuliah Kerja Nyata (KKN) memiliki beberapa tujuan penting diantaranya adalah memetakan potensi-potensi desa yang ada pada Desa Hargotirto sebagai desa Kelompok 2 Unit A ditempatkan. Lalu kegiatan KKN ini juga dapat meningkatkan pemahaman terhadap potensi yang ada di Desa Hargotirto serta memberikan nilai tambah untuk perekonomian masyarakat disana. Peningkatan perekonomian masyarakat juga bisa dilakukan dengan pengembangan sektor-sektor ekonomi mikro berupa industri rumah tangga yang ada di Desa Hargotirto, Kecamatan Kokap, Kulon Progo, Daerah Istimewa Yogyakarta. Selain tujuannya bagi masyarakat, tentu kegiatan $\mathrm{KKN}$ ini juga memiliki manfaat bagi mahasiswa. Dengan adanya kegiatan KKN, mahasiswa dapat mendapat pengalaman baru tentang bagaimana cara menerapkan dan mengembangkan ilmu teknologi di luar kampus. Mahasiswa juga dilatih untuk lebih terampil dalam memecahkan permasalahan yang 
ada di lingkungan masyarakat. Dan juga, mahasiswa dapat meningkatkan kecakapannya dalam merancang wirausaha dan turut berperan dalam mempersiapkan diri dalam dunia usaha industri.

Terdapat beberapa desa di wilayah kota Yogyakarta yang sudah disiapkan oleh Universitas Atma Jaya Yogyakarta sebagai tempat untuk setiap kelompok mengembangkan potensi desanya. Kelompok 2 Unit A mendapatkan tempat untuk kegiatan Kuliah Kerja Nyata di Desa Hargotirto. Desa Hargotirto merupakan salah satu desa yang terletak di Kecamatan Kokap, Kabupaten Kulon Progo, Daerah Istimewa Yogyakarta [1]. Secara geografis, Desa Hargotirto terletak di wilayah Pegunungan Menoreh dengan ketinggian antara 500 - 1000 meter di atas permukaan air laut. Desa Hargotirto memiliki luas wilayah sebesar $1.471 \mathrm{Ha}$ yang terbagi menjadi 14 padukuhan, $30 \mathrm{RW}$, dan 70 RT. Desa Hargotirto juga memiliki tingkat curah hujan yang cukup tinggi, yaitu sekitar 1500$2800 \mathrm{~mm} /$ tahun [1]. Secara demografis, sebagian besar masyarakat Desa Hargotirto memiliki mata pencaharian sebagai petani, pedagang, dan pengerajin gula kelapa yang diproduksi dalam skala rumah tangga. Potensi gula kelapa merupakan potensi yang paling sering ditemukan disana, namun masih terdapat banyak potensi lainnya yang dapat dikembangkan oleh Kelompok 2 Unit A.

Dengan tujuan untuk membantu Desa Hargotirto dalam mengembangkan potensi-potensi yang dimiliki, mahasiswa perlu mengamati potensi apa saja yang terdapat di Desa Hargotirto dan program kerja apa yang bisa dikembangkan disana. Potensi desa sendiri memiliki arti yakni kemampuan dari suatu desa yang memiliki kemungkinan untuk dapat dikembangkan, tujuannya adalah untuk menyejahterakan masyarakat di desa tersebut [2]. Potensi desa terbagi menjadi dua macam yakni potensi fisik seperti air, tanah, lingkungan geografis, dan binatang, dan potensi non-fisik yang berupa interaksi dengan masyarakat, lembaga pendidikan, sosial organisasi desa, dan sebagainya. Tujuan lain dari kegiatan KKN selain mengembangkan potensi yang ada di desa tertentu adalah meningkatkan perekonomian masyarakat. Peningkatan atau pembangunan ekonomi masyarakat merupakan salah satu bagian dari konsep pemberdayaan masyarakat. Dimana pemberdayaan masyarakat memiliki nilai-nilai untukmembangun pola baru dalam pembangunan yang sifatnya peoplecentered, participatory, empowerment, dan sustainable [3]. Pemberdayaan masyarakat memiliki tujuan untuk mencari alternatif untuk menumbuhkan perekonomian lokal. Pada jurnal ini akan dibahas mengenai potensi-potensi desa yang ada di Desa Hargotirto serta fokus dari program kerja Kelompok 2 Unit A.

\section{METODE PENGABDIAN}

Kuliah Kerja Nyata atau KKN periode 79 yang dilaksanakan oleh Universitas Atma Jaya menggunakan model KKN Society 5.0. Hal tersebut dikarenakan adanya pandemi Covid-19 yang masih terjadi di Indonesia. Kegiatan KKN dilakukan secara daring supaya menghindari adanya penerjunan mahasiswa langsung ke lapangan yang berisiko penambahan kasus virus Covid-19, khususnya di Yogyakarta. Kegiatan KKN periode 79 ini dilaksanakan mulai dari tanggal 01 April 2021 hingga 31 Mei 2021. Program KKN sendiri terbagi menjadi dua yakni program kelompok dan individu. Untuk program KKN kelompok ini, setiap kelompok diharuskan untuk membuat sebuah program kerja yang nantinya akan menghasilkan 1 laporan, 1 jurnal, 2 video dan 2 e-book yang membahas mengenai pengembangan potensi Desa Hargotirto dan program kerja yang kelompok pilih baik itu buku saku atau buku ajar untuk dapat membantu maupun mengedukasi warga Desa Hargotirto.

Akibat KKN yang dilaksanakan secara online dengan tema KKN Society 5.0, kelompok maupun individu harus mengumpulkan berbagai data informasi mengenai Desa Hargotirto hanya melewati sumber sekunder atau dari internet. Sebelum menghasilkan output yakni program KKN itu sendiri, kelompok perlu melewati tahapantahapan seperti tahapan untuk menentukan topik, mencari literatur, metode untuk analisis, metode pembuatan laporan, e-book, dan juga video, serta tahapan disksi serta bimbingan bersama dosen pembimbing.

\section{Metode Penentuan Topik}

Penentuan topik merupakan langkah awal sebelum kelompok bekerja mengembangkan program kerja kelompoknya. Saat ingin menentukan topik program kerja yang dilakukan oleh kelompok, pertama-tama anggota kelompok harus melakukan diskusi untuk mencari apa saja potensi desa yang terdapat di Desa Hargotirto melalui website Kabupaten Kulon Progo. Setelah melakukan diskusi kelompok, hasil temuan potensi desa ini dapat disampaikan dan diajukan kepadam Dosen Pembimbing Lapangan (DPL). Disini dosen pembimbing akan menyarankan potensi desa mana yang sekiranya memiliki potensi tinggi untuk dilanjutkan sebagai sebuah program kerja. 


\section{Metode Pencarian Literatur}

Dengan adanya model KKN secara daring dengan model KKN Society 5.0., kelompok secara terpaksa tidak dapat memperoleh data secara langsung melalui masyarakat Desa Hargotirto. Maka proses pencarian data literatur terkait keadaan di Desa Hargotirto hanya dapat dilakukan dengan mengandalkan website internet maupun jurnal-jurnal lain sebagai referensinya. Secara garis besar, kelompok mendapatkan data dari website resmi Kabupaten Kulon Progo bagian Desa Hargotirto. Namun, tidak semua data yang diinginkan terdapat di website, maka kelompok berusaha untuk mencari jurnal-jurnal terdahulu yang pernah dihasilkan oleh penulis lain mengenai potensi Desa Hargotirto. Melalui jurnal-jurnal tersebut, kelompok bisa mendapatkan hasil yang lebih baru dibandingkan data dari website.

\section{Metode Analisis}

Setelah melalui tahapan penentuan topik dan pencarian literatur, kelompok harus melalui proses analisis untuk melihat permasalahan seperti apa yang ada di Desa Hargotirto yang sekiranya dapat dibantu oleh Kelompok 2 Unit A. Pada proses analisis, kelompok menemukan banyak potensi yang ada di Desa Hargotirto, salah satunya adalah komoditas kelapa. Namun dari hasil pencarian melalui internet, kelompok hanya menemukan bahwa pemanfaatan kelapa di Desa Hargotirto sebagian besar diperuntukan untuk pembuatan gula semut. Maka kelompok memutuskan untuk membuat program pengembangan dan pemanfaatan kelapa di Desa Hargotirto untuk dijadikan minyak. Kelompok berharap dengan pembuatan program kerja tersebut, perekonomian di Desa Hargotirto dapat meningkat.

\section{Metode Pembuatan Laporan, E-Book, Video}

Seperti yang sudah dijelaskan di atas, terdapat beberapa luaran atau output dari kegiatan Kuliah Kerja Nyata ini yakni laporan, e-book, dan juga video. Pertama-tama, kelompok membagi job desk untuk masing-masing output dengan penanggung jawabnya masing-masing. Setelah itu anggota kelompok membuat laporan untuk bab 1 hingga bab 3 terlebih dahulu. Sembari pengerjaan laporan tersebut, terdapat beberapa anggota kelompok lainnya yang membuat $e$-book potensi desa dan buku saku dengan aplikasi atau website Canva. Melalui aplikasi tersebut, kelompok dapat membukukan pengembangan potensi desa yakni pemanfaatan kelapa sebagai minyak dan pembuatan program buku saku secara lebih singkat, padat, dan jelas. Selain itu, di dalam e-book juga terdapat langkah-langkah yang ditunjukkan secara visual, agar pembaca dapat mengetahui dengan jelas langkah demi langkah proses pembuatan minyak dari kelapa. Sedangkan untuk proses pembuatan video, terdapat beberapa anggota beserta penanggung jawabnya yang mengolah hasil e-book ke dalam bentuk video singkat. Video pengembangan potensi desa dan program buku saku sama-sama memiliki minimal durasi yakni 7 menit. Video dibuat dengan aplikasi Microsoft Powerpoint yang kemudian akan diisi dengan backsound lagu dan voice over singkat penjelasan dari isi video tersebut.

\section{Metode Diskusi dan Bimbingan}

Metode yang terakhir merupakan metode yang sangat penting untuk dilakukan yakni metode diskusi dan bimbingan. Setiap kelompok termasuk Kelompok 2 harus melakukan diskusi kelompok secara rutin supaya program kegiatan KKN ini dapat berjalan dan diselesaikan dengan tepat waktu. Proses diskusi dilakukan dengan dua aplikasi yakni WhatsApp yakni diskusi singkat via chat dan Microsoft Teams yakni untuk diskusi lebih lama dan lebih detailnya. Selain itu Kelompok 2 juga akan melakukan diskusi dan bimbingan dengan Dosen Pembimbing Lapangan dengan menggunakan aplikasi WhatsApp dan Microsoft Teams. Kedua aplikasi tersebut aktif digunakan oleh DPL dan anggota kelompok untuk menyampaikan progress terkait dengan laporan, video dan e-book yang dibuat, baik secara kelompok maupun individu. DPL dengan anggota kelompok juga melakukan meet setiap dua minggu sekali melalui Microsoft Teams. Tujuan dari adanya meet atau bimbingan ini adalah supaya dosen pembimbing dapat mengetahui perkembangan atau progres dari pekerjaan setiap kelompok. Selain itu dengan adanya bimbingan, setiap kelompok maupun individu dapat berkonsultasi mengenai kendala yang dihadapi terkait pelaksanaan KKN ini. Bimbingan dengan DPL dilakukan setiap hari sabtu dengan waktu bimbingan sekitar 30-45 menit setiap kelompok.

\section{HASIL DAN PEMBAHASAN}

Dari seluruh tahapan yang sudah dilalui, Kelompok 2 Unit A menemukan enam potensi desa yang terdapat di Desa Hargotirto. Potensi desa tersebut diantaranya adalah potensi pengembangan gula semut, kesenian Jatilan, Wisata Alam Curug Sekrasak, peternakan kambing, komoditas buahbuahan, dan produksi minyak kelapa (VCO) [1]. Mulai dari pengembangan gula semut, pada dasarnya Desa Hargotirto memiliki hasil pertanian lokal yang cukup baik dan bisa dioptimalkan untuk membuat olahan nira. Olahan nira ini nantinya dapat diolah kembali untuk menghasilkan gula semut atau kristal [4]. Namun karena adanya kebiasaan yang sudah terbentuk sejak dahulu, aplikasi penerapan teknologi secara modern untuk memproduksi gula masih belum optimal. 
Potensi yang kedua merupakan potensi budaya yakni kesenian Jatilan. Seni Jatilan adalah kesenian yang paling tua di Pulau Jawa dimana kesenian ini populer dan digemari oleh sebagian besar kalangan masyarakat Desa Hargotirto. Kesenian Jatilan biasanya dipentaskan saat warga desa menggelar hajatan atau acara-acara hari besar. Namun memang kesenian Jatilan di Desa Hargotirto belum sebesar kesenian Jatilan di desa lainnya [5]. Selain potensi budaya, terdapat potensi alam berupa Wisata Alam Curug Sekrasak. Desa Hargotirto berada di wilayah pegunungan yang banyak didominasi oleh perbukitan. Hal ini membuat banyak potensi wisata alam bermunculan di sekitar Desa Hargotirto, salah satunya adalah objek wisata air terjun Curug Sekrasak [6]. Hal yang masih bisa dikembangkan dari potensi alam di Curug Sekrasak adalah pengenalan dan pembuatan rambu-rambu pada objek wisata yang masih belum banyak ditemukan.

Potensi yang selanjutnya adalah potensi peternakan kambing, dimana kambing jenis etawa menjadi sumber utama dari pendapatan tambahan masyarakat Desa Hargotirto [7]. Kambing etawa juga memiliki potensi kualitas daging yang baik untuk diproduksi serta dapat menghasilkan susu kambing segar [8]. Desa Hargotirto juga memiliki potensi berupa komoditas buah-buahan. Desa Hargotirto dikenal sebagai penghasil buah-buahan lokal berkualitas tinggi, potensi buah-buahan yang ada disana antara lain manggis dan durian. Komoditas buah-buahan di Desa Hargotirto cukup besar karena adanya warisan lahan dan tanaman yang tumbuh di Desa Hargotirto dan lahan yang subur, maka cocok untuk area perkebunan [9].

Potensi yang terakhir adalah rencana produksi Virgin Coconut Oil (VCO) atau minyak dari kelapa. Minyak kelapa murni atau yang lebih dikenal dengan Virgin Coconut Oil (VCO) merupakan minyak kelapa yang diproduksi dengan hasil modifikasi sehingga produk yang dihasilkan mengandung kadar air dan kadar asam lemak bebas yang rendah dibandingkan dengan minyak kelapa biasa [10]. Desa Hargotirto memiliki komoditas kelapa yang cukup banyak sehingga VCO dapat menjadi salah satu potensi usaha yang dapat dilakukan untuk meningkatkan pendapatan masyarakat.Dari antara keenam potensi-potensi tersebut, Kelompok 2 memilih untuk melakukan pengembangan dan pemanfaatan kelapa menjadi minyak. Kelapa diketahui menjadi komoditas yang cukup banyak di Desa Hargotirto, namun kelompok mengamati dan menganalisis bahwa pemanfaatan komoditas kelapa selama ini hanya dimanfaatkan untuk memproduksi gula semut atau gula kelapa. Kelompok melihat bahwa masyarakat Desa
Hargotirto dapat memanfaatkan potensi komoditas kelapa menjadi produk lain, yaitu minyak.

Alat yang diperlukan untuk membuat minyak dari kelapa antara lain adalah pisau, alat pemarut kelapa (baik tradisional maupun dengan alat), spatula atau sotil, baskom, dan panci. Bahan yang perlu disiapkan tentunya adalah kelapa tua sebanyak 8 butir dan juga air bersih secukupnya. Langkah-langkah pembuatan minyak kelapa dapat dilihat di bawah ini.

1. Siapkan kelapa tua sejumlah 8 buah. Kelapa yang dipilih adalah yang tua karena kelapa tua lebih banyak santannya dan menghasilkan lebih banyak minyak.

2. Langkah berikutnya adalah belah kelapa menjadi 2 bagian.

3. Kupas kelapa dan dibersihkan.

4. Siapkan parutan kelapa dan parut kelapa yang sudah dibersihkan.

5. Kemudian peras hasil parutan kelapa dengan air supaya menghasilkan santan pada gambar 1 .

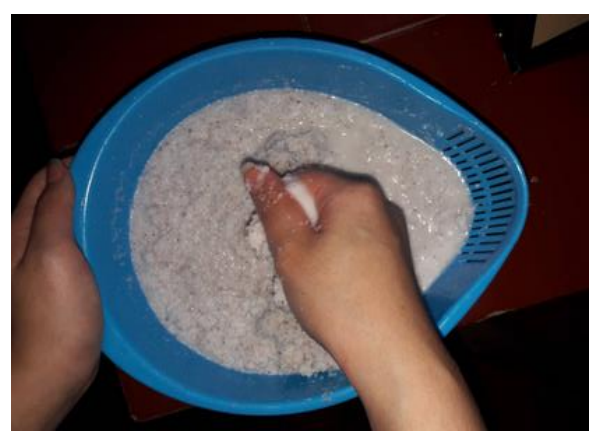

Gambar 1. Langkah Ke-5

6. Pisahkan parutan kelapa yang sudah diperas dan letakkan di atas piring atau baskom.

7. Lalu saring sisa parutan kelapa untuk mendapatkan santan pada gambar 2 .

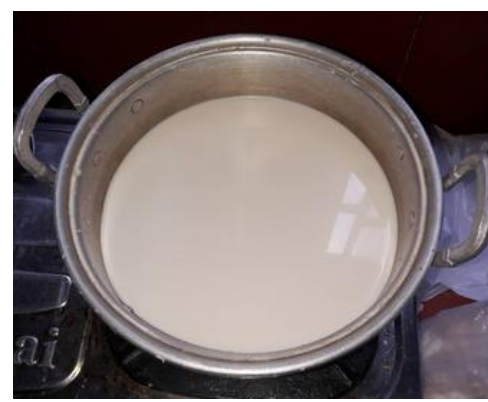

Gambar 2. Langkah Ke-7

8. Proses selanjutnya adalah menghangatkan santan di atas kompor atau tungku. Pada proses ini pastikan santan tidak sampai mendidih. 
9. Jika santan sudah mulai mengambang seperti gambar di bawah, api dapat dimatikan seperti gambar 3 .

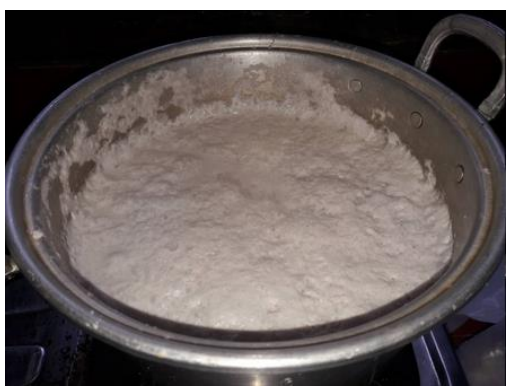

Gambar 3. Langkah Ke-9

10. Bagian putih yang mengambang pada santan kemudian dipisahkan secara perlahan. Jangan sampai mengaduk bagian bawah seperti pada gambar 9 .

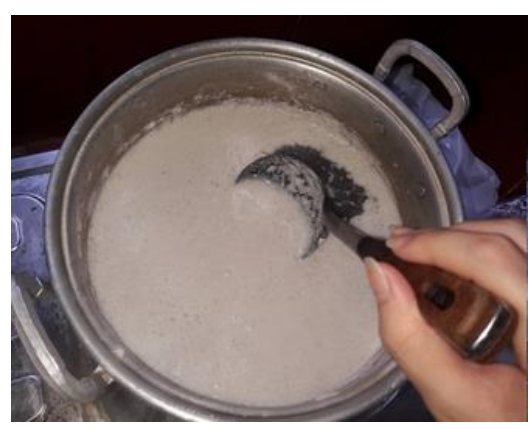

Gambar 4. Langkah Ke-10

11. Pada gambar 11, bagian putih tadi kemudian dipisahkan dan dipanaskan kembali di atas kompor atau tungku sekitar 1-2 jam.

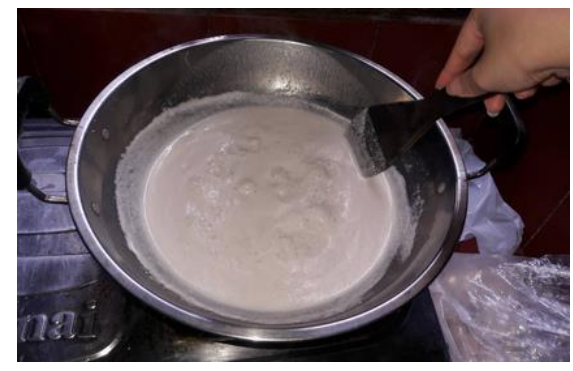

Gambar 5. Langkah Ke-11

12. Sembari santan dimasak, bagian pinggir dari wajan harus sering diaduk supaya tidak menimbulkan kerak.

13. Setelah santan dimasak selama 30 menit - 1 jam, santan akan berubah warna menjadi sedikit kekuningan disertai dengan buihbuih. Bagian pinggir wajan tetap harus sering diaduk.

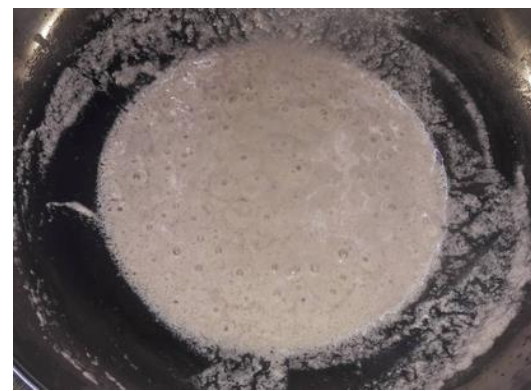

Gambar 6. Langkah Ke-13

14. Santan kemudian akan mulai berubah menjadi minyak setelah proses memasak sekitar 1,5 jam. Minyak diaduk terus hingga kuning dan supaya tidak gosong.

15. Santan yang berubah menjadi minyak akan menghasilkan sisa-sisa yang disebut Galendo.

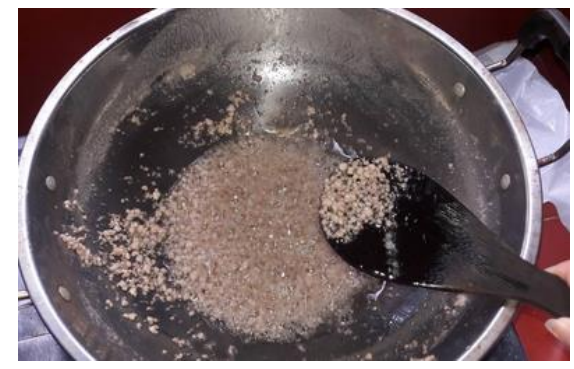

Gambar 7. Langkah Ke-15

16. Tanda bahwa minyak sudah jadi adalah saat Galendo berubah warna menjadi kuning keemasan.

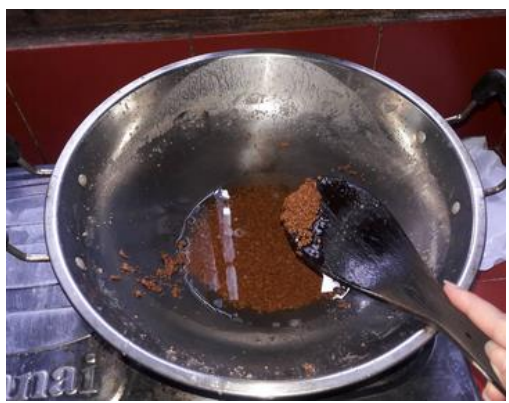

Gambar 8. Langkah Ke-16

17. Wajan kemudian diangkat dan minyak yang sudah jadi kemudian disaring. Sedangkan Galendo dapat dimakan.

18. Dari 8 butir kelapa tua sebenarnya dapat menghasilkan minyak sebanyak $1 / 2$ liter. Setelah itu minyak dapat dimanfaatkan sebagai minyak goreng. 


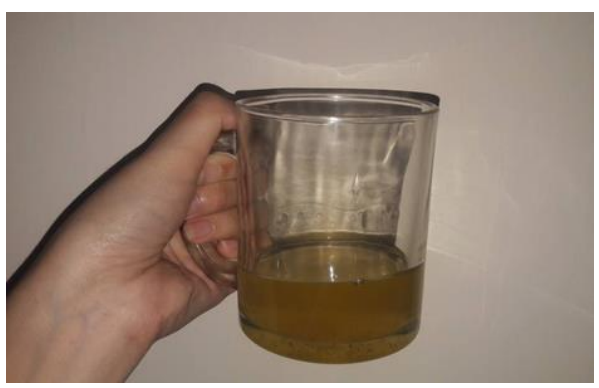

Gambar 9. Langkah Ke-18

Minyak dari kelapa yang sudah dijelaskan langkah-langkahnya di atas memiliki beberapa manfaat baik itu bagi kesehatan maupun secara ekonomis. Bagi kesehatan, minyak dapat mencegah penyakit jantung, kanker, dan diabetes. Minyak juga bisa mencegah terjadinya infeksi karena virus dan mencegah kerutan serta penuaan diri. Minyak dari kelapa dapat meningkatkan kekebalan tubuh dan menopang pertumbuhan serta perkembangan pada anak. Selain itu, minyak dari kelapa bisa dimanfaatkan sebagai bahan untuk membuat obat dan kosmetik. Sedangkan secara ekonomis, pembuatan minyak secara mandiri dapat menghemat pengeluaran dan dapat dijadikan peluang bisnis karena memiliki nilai jual yang tinggi.

\section{KESIMPULAN}

Pada program kerja potensi desa, kelompok 2 menemukan bahwa komoditas kelapa di Desa Hargotirto lebih banyak digunakan untuk proses pembuatan gula semut, sementara pengolahan minyak kelapa masih belum banyak dilakukan. Oleh karena itu, Kelompok 2 memutuskan untuk mendukung pengembangan pemanfaatan kelapa melalui produksi minyak kelapa. Dengan adanya sumber daya alam berupa pohon kelapa, Kelompok 2 berharap warga Desa Hargotirto dapat mengolah hasil buah kelapa menjadi minyak secara mandiri. Diharapkan pula pengolahan minyak kelapa secara mandiri dapat membantu meningkatkan perekonomian warga Desa Hargotirto dan memunculkan adanya peluang usaha. Selain itu, mengkonsumsi minyak dari kelapa juga relatif lebih sehat dibandingkan minyak goreng pada umumnya 


\section{UCAPAN TERIMAKASIH}

Kami juga berterima kasih kepada pihak LPPM dan Universitas Atma Jaya karena sudah menyelenggarakan kegiatan $\mathrm{KKN}$ ini dengan baik dan lancar.

\section{DAFTAR PUSTAKA}

[1] "Kalurahan Hargotirto," 2016. http://hargotirto-kulonprogo.desa.id/.

[2] K. Endah, "Pemberdayaan Masyarakat : Menggali Potensi Lokal Desa," Moderat J. Ilm. Ilmu Pemerintah., vol. 6, no. 1, pp. 135-143, 2020.

[3] N. Margolang, "Pemberdayaan Masyarakat," Dedik. J. Community Engag., vol. I, no. 2, pp. 87-99, 2018, doi: $10.31227 /$ osf.io/weu8z.

[4] E. Merbawani and R. R, "Strategi Penghidupan Masyarakat Penghasil Gula Semut di Desa Hargotirto, Kecamatan Kokap, Kabupaten Kulon Progo," J. Bumi Indones., 2016.

[5] "Dinas Kebudayaan Kulon Progo." https://disbud.kulonprogokab.go.id/.

[6] M. Naufal, Darrotunafisah, B. J. Muhammad, and R. F. Putri, "MPGIS : MAP OF POTENTIAL GEOTOURISM BASED ON GIS SEBAGAI STRATEGI PENGEMBANGAN WISATA PANDANG DI KECAMATAN KOKAP, KABUPATEN Indonesia memiliki karateristik alam dan lingkungan yang sangat beragam terutama dalam hal keindahan pemandangan alam . Kondisi sa," no. September, pp. 1283-1295, 2018.

[7] H. Nurulia, C. A. Artdita, and F. B. Lestari, "Pengaruh Karakteristik Peternak ...

Nurulia H , Clara Ajeng A \& Fajar Budi L PENGARUH KARAKTERISTIK PETERNAK TERHADAP ADOPSI TEKNOLOGI NURULIA HIDAYAH Universitas Gadjah Mada CLARA AJENG ARTDITA Jurnal Bisnis \& Manajemen," J. Bisnis dan Manaj., vol. 19, pp. 1-10, 2019.

[8] M. R. Ridlo, "Perbaikan Manajemen Reproduksi Kambing Peranakan Etawah Melalui Sosialisasi dan Pelatihan kepada Kelompok Ternak Subur Kokap Kulon Progo DIY," J. Pengabdi. dan Pengemb. Masy., vol. 1, no. 1, pp. 75-80, 2018, doi: 10.22146/jp2m.41622.

[9] D. Mutakin, "Intensitas Konsumsi Pangan Lokal Sumber Karbohidrat Non Beras Dalam Upaya Diversifikasi Pangan Di Desa Hargorejo Kecamatan Kokap Kabupaten Kulon Progo,” J. Geogr. Gea, vol. 17 , no. 1 , p. 92,2017 , doi: 10.17509/gea.v17i1.5943.
[10] Wisnubrata, "Manfaat Minyak VCO, Salah Satunya untuk Menurunkan Berat Badan," 2020.

https://lifestyle.kompas.com/read/2020/07/ 13/151717320/manfaat-minyak-vco-salahsatunya-untuk-menurunkan-berat-badanlho? page $=$ all . 


\section{PENULIS}

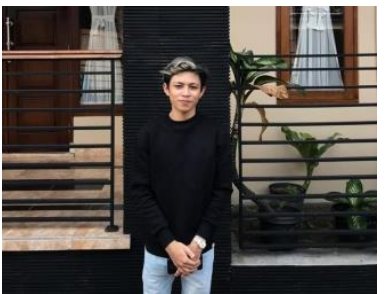

\section{Muhammad Fajar Sidiq}

Program Studi Akuntansi

Fakultas Bisnis dan Eknomika

Univerisitas Atma Jaya

Yogyakarta

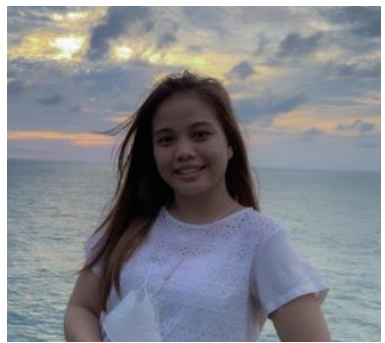

\section{Yulia Oktaviani V}

Program Studi Teknik Sipil

Fakultas Teknik

Univerisitas Atma Jaya Yogyakarta

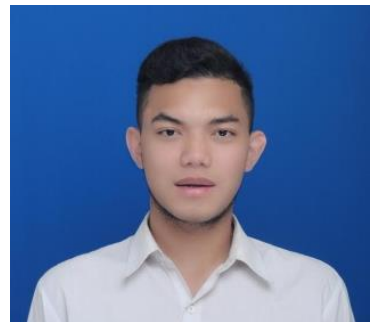

\section{Ferdian Ravanelli \\ Program Studi Manajemen \\ Fakultas Bisnis dan Ekonomika \\ Univerisitas Atma Jaya Yogyakarta}

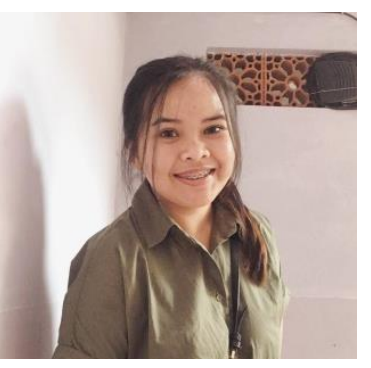

\begin{tabular}{|c|}
\hline Tessya Christara \\
Program Studi Ilmu Hukum \\
Fakultas Hukum \\
Univerisitas Atma Jaya \\
Yogyakarta
\end{tabular}
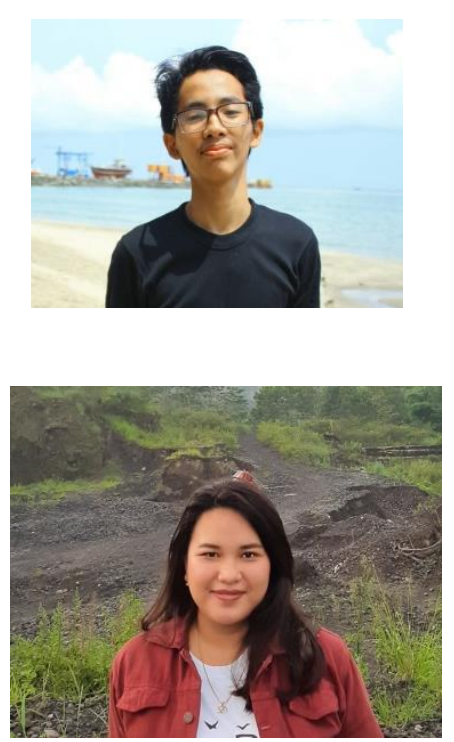

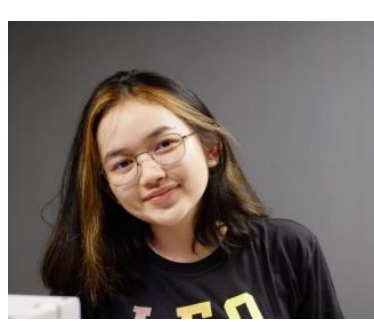

\section{Eudia Yulian H}

Program Studi Sistem Informasi

Fakultas Teknologi Industri

Univerisitas Atma Jaya Yogyakarta

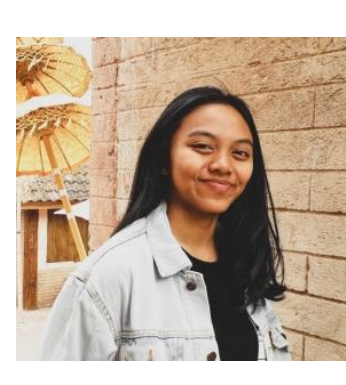

Maria Nariswari

Program Studi Ilmu

Komunikasi

Fakultas Ilmu Sosial dan

Politik

Univerisitas Atma Jaya

Yogyakarta

\section{Zefanya Atalya}

Program Studi Teknik Industri

Fakultas Teknologi Industri

Univerisitas Atma Jaya

Yogyakarta

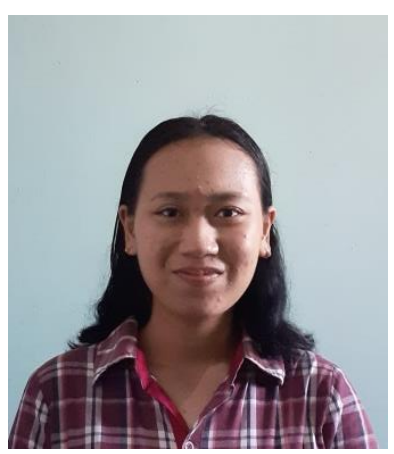

Mardyaning Christ C

Program Studi Ilmu

Komunikasi

Fakultas Ilmu Sosial dan Politik

Univerisitas Atma Jaya Yogyakarta

Program Studi Teknik Informatika

Fakultas Teknologi Industri

Univerisitas Atma Jaya Yogyakarta

\section{Maria Andreeana L}

Program Studi Ekonomi

Pembangunan

Fakultas Bisnis dan Eknomika

Univerisitas Atma Jaya Yogyakarta

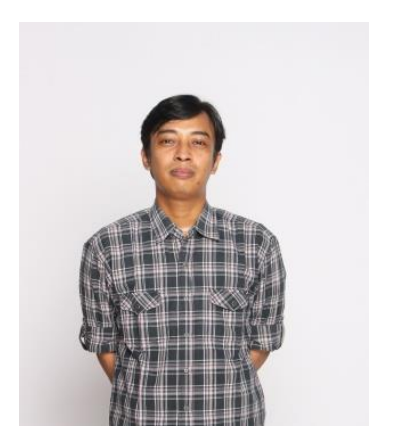

A. Aryo Lukisworo

Program Studi Sosiologi

Fakultas Ilmu Sosial dan Politik

Univerisitas Atma Jaya Yogyakarta 